\title{
PENGEMBANGAN PARIWISATA MEDIS BERBASIS TANAMAN OBAT DI DESA WANAGIRI - BEDUGUL
}

\author{
Made Handijaya Dewantara \\ Email: handi.dewantara@pib.ac.id \\ POLITEKNIK INTERNASIONAL BALI
}

\begin{abstract}
This study intends to describe the opportunities and threats that could be used as consideration for the development of medical tourism in the village of Wanagiri, Bedugul, as well as to know how the process of managing this type of tourism. The study then conducted through the data collection techniques such as interviews and observations in the village Wanagiri, Bedugul, and analyzed by qualitative descriptive. Medical tourism became the basis of returning the authenticity of tourism in Bali based on cultures and values of their ancestors, in order to face global economy. Through the research process can be concluded that the chances of developing the cultivation of medical plants is still very open broadly in line with the development of herbal industry, medicine, and traditional cosmetics in the village Wanagiri, Bedugul. In relation to tourism, the utilization of medical plants can certainly be an attraction for tourists to know the types, utilization, and processing of medical plants until they are ready for consumption. Through this alternative tourism activities, the benefits are not only felt by tourists who come, but also for the surrounding community in the village Wanagiri, Bedugul.
\end{abstract}

Keywords: Medical Tourism, Village Wanagiri, Bedugul, Medical Plants

\begin{abstract}
Abstrak
Penelitian ini bermaksud untuk menggambarkan peluang dan ancaman yang dapat digunakan sebagai pertimbangan untuk pengembangan wisata medis di Desa Wanagiri, Bedugul, serta untuk mengetahui bagaimana proses pengelolaan jenis wisata ini. Penelitian dilakukan melalui teknik pengumpulan data seperti wawancara dan observasi di desa Wanagiri, Bedugul, dan dianalisis secara deskriptif kualitatif. Wisata medis menjadi dasar mengembalikan keaslian pariwisata di Bali berdasarkan budaya dan nilai-nilai leluhur masyarakat, dalam rangka menghadapi ekonomi global. Melalui proses penelitian dapat disimpulkan bahwa peluang pengembangan budidaya tanaman obat masih sangat terbuka luas seiring dengan berkembangnya industri jamu, obatobatan, dan kosmetik tradisional di Desa Wanagiri, Bedugul. Dalam kaitannya dengan pariwisata, pemanfaatan tanaman medis tentu dapat menjadi daya tarik bagi wisatawan untuk mengetahui jenis, pemanfaatan,
\end{abstract}


dan pengolahan tanaman medis sampai siap untuk dikonsumsi. Melalui kegiatan wisata alternatif ini, manfaatnya tidak hanya dirasakan oleh wisatawan yang datang, tetapi juga bagi masyarakat sekitar di desa Wanagiri, Bedugul.

Kata Kunci: Wisata Medis, Desa Wanagiri, Bedugul, Tanaman Obat

\section{PENDAHULUAN}

Dalam industri pariwisata, pariwisata medis telah muncul sebagai alternatif pariwisata dari beberapa jenis produk pariwisata. Beberapa negara telah secara aktif mengembangkan jenis industri ini sambil mendapatkan perhatian lebih dari pemerintah. Diperkirakan bahwa jenis industri pariwisata medis, saat ini menghasilkan pendapatan tahunan hingga US \$ 60 miliar (negatif 40 miliar), memberikan kontribusi bagi pertumbuhan pariwisata tahunan sebesar 20\% (Herrick, 2007). Jumlah wisatawan yang tertarik (dikategorikan sebagai wisatawan medis) juga meningkat, dari 19 juta wisatawan pada tahun 2005 menjadi 25,8 juta pada tahun 2007, dengan tingkat pertumbuhan tahunan sebesar 16,5\%. Pertumbuhan jumlah wisatawan diduga karena ketidakmampuan obatobatan biasa dalam menjamin penyembuhan penyakit. Jenis perawatan herbal ini juga tidak mengandung efek samping. Pariwisata medis menjadi semakin populer, ketika banyak orang dari negara berkembang pergi ke negara maju, terutama untuk kategori menengah ke atas, untuk mendapatkan perawatan kesehatan dan fasilitas yang lebih baik. Di sisi lain, beberapa wisatawan dari negara maju pergi ke negara berkembang, untuk memenuhi rasa ingin tahu tentang wisata medis alternatif, yang dikenal menggunakan alam lebih dari sumber mineral obat.

Ada dua definisi "wisata medis" yang dapat ditemukan dalam literatur atau internet. Definisi pertama, pariwisata kesehatan sebagai alternatif pariwisata mengacu pada perjalanan dengan tujuan memperoleh layanan kesehatan. Definisi kedua lebih umum digunakan dalam bisnis dan 
media, juga muncul dalam literatur pariwisata dan kesehatan. Organisasi Kesehatan Dunia merumuskan Pariwisata Medis sebagai kegiatan untuk melakukan perjalanan melintasi perbatasan internasional untuk menerima beberapa bentuk perawatan medis, baik untuk mendapatkan perawatan dapat menjangkau berbagai layanan medis, atau yang paling umum: perawatan gigi, bedah kosmetik, operasi elektif, dan perawatan kesuburan (Kelley, 2013: 2).

Sementara itu industri pariwisata memandang pariwisata medis sebagai kombinasi layanan medis dan layanan pariwisata, sementara industri medis kurang optimis pada kombinasi layanan medis dan layanan pariwisata. Oleh karena itu, pendekatan yang digunakan sangat berpengaruh dalam menentukan perspektif yang akan diberikan kepada kegiatan wisata medis. Cara terbaik menggunakan pendekatan dalam bidang ilmu pariwisata adalah dengan menggunakan teori pariwisata, pariwisata dibentuk berdasarkan berbagai disiplin ilmu, oleh karena itu dalam mendekati kegiatan pariwisata akan lebih baik menggunakan berbagai disiplin ilmu yang terkait.

Produk wisata medis dapat didefinisikan sebagai kelompok yang terdiri dari tujuan wisata medis (pasien) atau berbagai jenis layanan yang ditawarkan oleh layanan pariwisata medis (pasokan wisata). Ehrbeck (2008) membedakan produk berdasarkan jenis layanan yang ditawarkan oleh layanan medis menjadi enam bagian: operasi besar, operasi kecil, kosmetik / operasi plastik, layanan diagnostik, perawatan terapi alternatif, dan layanan gaya hidup / kesejahteraan. Menurut Raymon (2008), produk wisata medis dapat dikelompokkan menjadi enam bagian yang dapat dilihat dari tabel 1. 
Tabel 1. Produk Utama Pariwisata Medis

\begin{tabular}{|c|c|}
\hline $\begin{array}{c}\text { Cosmetic/Plastic } \\
\text { Surgeries }\end{array}$ & $\begin{array}{l}\checkmark \text { Facial cosmetic surgery: rhytidectomy, eyelid } \\
\text { surgery (blepharoplasty), nose reshaping, brow or } \\
\text { forehead lift, ear surgery: otoplasty } \\
\checkmark \text { Body contouring: liposuction (lipoplasty, tummy } \\
\text { tuck (abdominoplasty), breast augmentation } \\
\text { (augmentation mammoplasty), breast lift } \\
\text { (mastopexy), thigh lift, buttock lift, lower body } \\
\text { lift(belt lipectomy) }\end{array}$ \\
\hline \multicolumn{2}{|r|}{ Diagnostic Services } \\
\hline $\begin{array}{c}\text { Alternative Therapy } \\
\text { Treatments }\end{array}$ & $\begin{array}{l}\checkmark \quad \text { Chinese medicine, acupuncture, herbal treatments, } \\
\text { Ayurvedic treatments, } \\
\checkmark \quad \text { Pancha Karma, tai-chi }\end{array}$ \\
\hline $\begin{array}{l}\text { Wellbeing/Lifestyle } \\
\text { Remodeling Services }\end{array}$ & $\begin{array}{l}\checkmark \text { Spa therapy, yoga therapy, meditation therapy, } \\
\text { holistic therapy, thermal therapy (mineral springs, } \\
\text { balneo therapy), thermos therapy, thalasso } \\
\text { therapy, } \\
\checkmark \quad \text { Algae therapy, aroma therapy, cryo therapy, } \\
\text { electro therapy, magneto therapy, -healing } \\
\text { mud(fango therapy), occupational therapy(stress } \\
\text { management), massage(pampering), } \\
\text { diet(nutritional) programs, detox programs, New } \\
\text { Age, spiritual tourism }\end{array}$ \\
\hline Major Surgeries & $\begin{array}{l}\checkmark \quad \begin{array}{l}\text { Orthopedic surgeries: hip replacement, hip } \\
\text { resurfacing, knee replacement }\end{array} \\
\checkmark \quad \begin{array}{l}\text { Spinal procedures: spinal fusion, spinal disc } \\
\text { replacement }\end{array} \\
\checkmark \quad \text { Limited cardiac procedures: angioplasty, cardiac } \\
\text { diagnostic procedures } \\
\checkmark \quad \begin{array}{l}\text { Gynecological surgeries: partial hysterectomy, } \\
\text { total hysterectomy, radical Hysterectomy, }\end{array} \\
\text { bilateral salpingo oophorectomy } \\
\quad \begin{array}{l}\text { General surgeries: vascular, stomach and bowel, } \\
\text { kidney and urinary, gallbladder removal, Hernia }\end{array} \\
\text { repair, cataract surgery, LASIK surgery, } \\
\text { hemorrhoid removal, Endo laser vein surgery } \\
\text { Other medical procedures: bariatric surgery, } \\
\text { fertility treatment, Oncology, transplants, stem } \\
\text { cell treatments, sex reassignment, addiction } \\
\text { treatments }\end{array}$ \\
\hline Minor Surgeries & $\begin{array}{l}\checkmark \quad \text { Dental procedures: dental work, cosmetic } \\
\text { dentistry, crowns, bonding, veneers, whitening, } \\
\text { bridges, bone grafts, root canals, tooth extractions } \\
\checkmark \quad \text { Eye, ear, nose, and throat treatments }\end{array}$ \\
\hline
\end{tabular}


Antara 6 faktor tersebut yang membentuk produk wisata medis masing-masing memiliki empat komponen yang dibutuhkan dan saling mempengaruhi. Keempat komponen terdiri dari fasilitas medis dan layanan terkait, akomodasi dan layanan F \& B, fasilitas wisata dan layanan terkait, serta kebijakan pemerintah dan faktor sosiokultural. Membentuk enam wisata medis ini sebenarnya merupakan peluang besar untuk tujuan wisata, di negara tropis, tidak terbatas pada Indonesia, dan bahkan Bali.

Bali telah dikenal sebagai salah satu tujuan wisata internasional terbaik, bahkan TripAdvisor sebagai situs web acuan terkemuka telah menamai Bali sebagai tujuan terbaik di 2016. Pulau ini terkenal dari budaya dan alamnya, yang dapat menarik jutaan pengunjung setiap tahun. Pulau ini tidak hanya terkenal dari pantai, tempat wisata alam, danau, bukit, tetapi juga dari perkebunan. Salah satu desa yang terkenal adalah desa Wanagiri, Bedugul, yang terletak di daerah pegunungan dan dekat dengan pusat studi tanaman di Kebun Raya Eka Karya, tentu saja, memiliki potensi untuk jumlah tanaman Medis yang tersedia.

Sayangnya, desa ini tidak berkembang dengan baik. Kekayaan sumber daya alam medis belum dikelola oleh para pemangku kepentingan pariwisata. Mempertimbangkan lokasi, bisnis medis pariwisata dapat dikembangkan di daerah ini. Selain itu, jenis penyembuhan di usada, yang juga merupakan perawatan khas Bali akan menarik untuk digabungkan menjadi produk wisata medis.

\section{TINJAUAN PUSTAKA}

Perkembangan pariwisata medis di Indonesia khususnya Bali juga memiliki peluang untuk tumbuh lebih besar, dengan potensi Bali sebagai tujuan wisata yang sangat populer di dunia. Maka kreativitas dalam menciptakan produk wisata baru sangat dibutuhkan, salah satunya adalah melalui wisata medis. Bali adalah tujuan wisata yang memiliki 
perencanaan pariwisata berbasis budaya, oleh karena itu sangat tepat jika produk wisata yang ditawarkan memiliki keaslian atau keunikan yang berasal dari budaya Bali itu sendiri. Dalam konsep produk pariwisata medis budaya Bali termasuk dalam kelompok alternatif, terapi dan perawatan di mana budaya memiliki istilah Usada.

Usada adalah pengetahuan tentang obat tradisional Bali, sebagai sumber konsep untuk memecahkan masalah kesehatan. Usada adalah alat yang ampuh untuk kampanye pariwisata medis di pulau ini. Ini juga merupakan titik diferensiasi antara pariwisata medis yang akan dilaksanakan di Bali, dibandingkan dengan tujuan wisata medis serupa lainnya seperti Singapura, Kualalumpur, Bangkok, dan Makau. Dengan menguasai konsep usada dan memanfaatkannya dalam kerangka konseptual di bidang pencegahan, pengobatan, rehabilitasi dan penelitian berguna untuk mengembangkan ilmu pengetahuan dan teknologi di bidang kesehatan. Kata usada berasal dari kata ausadhi (bahasa Sansekerta) yang berarti tumbuhan yang mengandung sifat-sifat Medis. Kata usada tidak asing bagi orang-orang di Bali, karena kata usada sering digunakan dalam percakapan sehari-hari dalam hal merawat orang sakit.

Sehubungan dengan pariwisata medis, usada adalah bagian dari produk wisata medis yang dibagi berdasarkan berbagai jenis layanan yang ditawarkan oleh layanan medis. Dalam pelaksanaannya Usada lebih banyak menggunakan tanaman Medis, di mana tanaman ini tumbuh dan berkembang dengan sangat baik di Bali, terutama di Desa Wanagiri, Bedugul.

\section{TANAMAN OBAT DI SEKITAR DESA WANAGIRI}

Tanaman obat dan manfaatnya dalam budaya Bali termasuk dalam usada (obat tradisional Bali) yang secara khusus dijelaskan dalam Lontar Usada Taru Pramana. Di lontar, dijelaskan bahwa ramuan obat berasal dari 
pertumbuhan tanaman. Mitologi tumbuhan yang bisa berbicara dan bercerita tentang keampuhan dirinya. Penggunaan tanaman medis untuk menyembuhkan penyakit dan mengobati kesehatan telah dilakukan selama berabad-abad. Dari catatan sejarah, orang pada umumnya memahami banyak hal tentang tanaman yang berguna sebagai obat dan cara menggunakannya. Tanaman yang merupakan bahan baku obat tradisional tersebar di seluruh Indonesia. Di hutan tropis Indonesia ada 30.000 spesies tanaman. Dari jumlah ini sekitar 9.600 spesies diketahui berkhasiat obat, tetapi hanya 200 spesies yang telah dimanfaatkan sebagai bahan baku dalam industri obat tradisional (B. Utomo, 2011:4).

Tanaman medis adalah tanaman yang memiliki sifat medis dan digunakan untuk penyembuhan dan pencegahan penyakit. Pemahaman tentang sifat medis adalah mengandung zat aktif yang berfungsi untuk mengobati penyakit tertentu atau jika tidak mengandung zat aktif tertentu tetapi mengandung efek yang dihasilkan / sinergi dari berbagai zat yang berfungsi untuk menyembuhkan. Tanaman medis didefinisikan sebagai spesies tanaman parsial, tanaman utuh dan atau eksudat tanaman digunakan sebagai obat, bahan, atau jamu. Secara umum, tanaman Medis menjadi tiga kelompok (B. Utomo dkk, 2007:11), yaitu:

1. Tanaman Tradisional adalah jenis tumbuhan yang diketahui atau diyakini memiliki khasiat medis dan telah digunakan sebagai bahan baku obat tradisional.

2. Tanaman medis modern adalah spesies tanaman yang telah terbukti secara ilmiah mengandung senyawa medis atau bahan bioaktif dan penggunaannya dapat dipertanggungjawabkan secara medis.

3. Potensi tanaman medis adalah spesies tanaman yang diduga mengandung atau memiliki senyawa atau bahan bioaktif Medis atau Medis tetapi belum terbukti kegunaan medis-ilmiahnya sebagai agen Medis. 
Sedangkan Kementerian Kesehatan RI mendefinisikan tanaman Medis Indonesia seperti yang tercantum dalam Keputusan Menteri Kesehatan Nomor 149 / SK / Menkes / IV / 1978, yaitu:

1. Tanaman atau bagian tanaman yang digunakan sebagai bahan obat tradisional atau jamu.

2. Tanaman atau bagian tanaman yang digunakan sebagai bahan awal bahan baku obat (prekursor).

3. Tanaman atau bagian dari tanaman diekstraksi dan ekstrak tumbuhan digunakan sebagai obat.

Tanaman medis biasanya tumbuh di tanah atau tanah yang dianggap tidak produktif seperti lereng atau jurang, cekungan sungai, dan rumah di halaman belakang. Efek samping obat tradisional relatif kecil bila digunakan dengan benar, termasuk kebenaran materi, ketepatan dosis, ketepatan waktu penggunaan, ketepatan penggunaan, akurasi tinjauan informasi, dan tanpa penyalahgunaan obat tradisional itu sendiri (Raymond, 2008). Meski masih memiliki kelemahan yaitu penggunaan atau pengolahan yang tidak praktis, kelebihan atau manfaat menggunakan tanaman medis menurut Dr. Budi Utomo, antara lain:

1. Tidak ada efek samping yang akan digunakan jika itu seperti yang direkomendasikan.

2. Efektif untuk menyembuhkan penyakit tertentu yang sering sulit disembuhkan oleh obat-obatan kimia.

3. Murah, mengingat itu umumnya ditanam di pekarangan rumah, yang paling umum ditemukan tumbuh liar, di kebun atau sawah sekitar.

4. Perawatan umumnya dapat dilakukan oleh anggota keluarga saja tanpa bantuan medis atau paramedis.

Peluang untuk pengembangan budidaya tanaman obat masih sangat terbuka lebar seiring dengan pertumbuhan jamu industri, obatobatan, herbal, fitofarmaka dan kosmetik tradisional. Dalam kaitannya 
dengan pariwisata, penggunaan tanaman medis tentu bisa menjadi daya tarik bagi wisatawan untuk mengetahui jenis, pemanfaatan dan pengolahan tanaman medis untuk siap konsumsi. Selain itu, khasiat tanaman medis untuk menyembuhkan penyakit dan mengobati kesehatan bisa menjadi layanan medis bagi wisatawan.

\section{OBJEK WISATA DAN OBJEK WISATA DI DESA WANAGIRI, BEDUGUL}

Desa Wanagiri, Bedugul adalah kecamatan Sukasada yang terletak sekitar 15 km di Kabupaten Buleleng Kabupaten Buleleng. Posisinya sangat strategis karena merupakan salah satu kecamatan penyangga lumbung padi Kabupaten Buleleng. Batas-batas Desa Wanagiri, Bedugul dibagian utara berbatasan dengan Desa Gitgit dan Gobleg Buleleng, dibagian timur berbatasan dengan Kebun Raya Bukit Bedugul dan Eka Karya, dibagian selatan berbatasan dengan Kecamatan Baturiti, dan dibagian barat berbatasan dengan Kebun Raya Bukit Bedugul dan Eka Karya

a. Kondisi Fisik

Desa Wanagiri, Bedugul termasuk dalam daerah pegunungan berbukit di utara dan lereng ke arah selatan dengan morfologi dan ketinggian wilayah dengan pembagian berikut : kemiringan 5-40\% dengan topografi berbukit yang terletak sebagian besar di wilayah utara, sedangkan dengan tipe morfologi bergelombang (kemiringan 2-5\%) terletak sebagian besar di wilayah selatan, untuk lereng 0-2\% yang menempati wilayah selatan di sebelah tenggara. Curah hujan relatif besar diwilayah utara (pegunungan dan berbukit), dengan batas-batas seperti yang disebutkan di atas. 


\section{b. Kondisi Perekonomian}

Penggunaan lahan di Wilayah Desa Wanagiri, Bedugul digunakan untuk sawah dan sisanya digunakan untuk permukiman dan penggunaan lainnya. Struktur ekonomi di Desa Wanagiri, Bedugul masih merupakan pola agraris yang terbukti dengan pemanfaatan lahan basah yang optimal oleh masyarakat.

Potensi wisata yang dimiliki oleh Desa Wanagiri, Bedugul yang dapat dikembangkan sebagai objek wisata medis terletak pada keanekaragaman vegetasi tumbuhan, terutama tanaman medis. Hampir semua rumah di Desa Wanagiri, Bedugul membudidayakan tanaman obat di rumah atau tanah yang tidak digunakan. Selain itu, situasi geografis Desa Wanagiri, Bedugul, yang terletak di daerah perbukitan dan kondisi iklim yang dingin menyebabkan tanaman tumbuh liar di jalan desa dan semak-semak, di mana tidak jarang tanaman ini dapat dimanfaatkan sebagai tanaman medis.

Daya tarik lain terletak pada kehidupan sosial masyarakat Desa Wanagiri, Bedugul. Penduduk Desa Wanagiri, Bedugul tidak hanya menanam tanaman Medis tetapi juga memiliki pengetahuan tradisional tentang pemanfaatan dan pengolahan tanaman medis dan diterapkan dalam kehidupan sehari-hari untuk perawatan kesehatan keluarga. Tanaman obat diolah dalam bentuk loloh dan herbal dan ada juga tanaman medis yang diolah menjadi makanan seperti bubur. Selain digunakan untuk perawatan kesehatan, tanaman medis juga digunakan untuk menyembuhkan penyakit, seperti daun binahong, jahe merah, daun wungu, alpukat. Selain vegetasi tanaman medis dan kehidupan sosial masyarakat desa, Desa Wanagiri, Bedugul juga memiliki kondisi alam yang masih alami dan kondisi iklim yang sejuk sehingga ada beberapa kegiatan wisata yang dapat dilakukan di Desa Wanagiri, Bedugul seperti Treking dan tamasya. 
c. Aksesibilitas

Lokasi Desa Wanagiri, Bedugul cukup strategis, dapat diakses melalui jalan raya provinsi Bedugul-Singaraja dengan melakukan perjalanan \pm 30 menit dari pusat kota Buleleng menggunakan kendaraan pribadi atau angkutan umum. Secara umum kondisi fisik jalan dapat mendukung kegiatan pariwisata di Desa Wanagiri, Bedugul.

d. Fasilitas

Fasilitas yang tersedia di dasa Wanagiri, Bedugul secara umum dapat mendukung pengembangan pariwisata di desa. Fasilitas yang terdapat di Desa Wanagiri, Bedugul meliputi penginapan, restoran, pasar tradisional, minimarket, tempat ibadah, namun jumlahnya masih terbatas. e. Ancilaries

Pemerintah Desa Wanagiri, Bedugul terdiri dari Kepala Desa, yang selanjutnya disebut Perbekel dan perangkat desa sebagai unsur pemerintahan desa. Tugas dan wewenang Perbekel salah satunya adalah urusan masyarakat adalah pemberdayaan masyarakat melalui pengembangan kehidupan sosial budaya masyarakat yang meliputi bidang kesehatan, pendidikan, kepabeanan, dan bidang lainnya.

\section{TINJAUAN PENGEMBANGAN PRODUK WISATA MEDIS DI DESA WANAGIRI, BEDUGUL}

Gambaran perkembangan produk Wisata Medis di Desa Wanagiri, Bedugul, dijelaskan melalui analisis kekuatan, kelemahan, peluang dan ancaman pengembangan produk wisata, sebagai berikut :

a. Kekuatan

Desa Wanagiri memiliki 4 kekuatan yang menopang keberadaan desa itu sendiri, yang meliputi :

1) Keanekaragaman vegetasi tumbuhan medis yang dimiliki oleh masyarakat Desa Wanagiri, Bedugul. Desa Wanagiri, Bedugul 
memiliki kelebihan tersendiri di mana di Desa Wanagiri, Bedugul sendiri banyak ditumbuhi beberapa jenis tanaman medis yang digunakan sebagai bahan utama dalam wisata medis. Jadi ketersediaan dalam memasok bahan utama produk dijamin. Berbagai varietas tanaman obat yang tumbuh di sekitar Desa Wanagiri, Bedugul beberapa diantaranya adalah sejenis tanaman obat yang tumbuh di lokasi dan iklim tertentu sehingga tidak semua tanaman medis dapat tumbuh di berbagai daerah sehingga jenis vegetasinya disesuaikan dengan tekstur tanah, dan iklim sekitar. Ini menjadi kekuatan masyarakat Desa Wanagiri, Bedugul dalam mengembangkan wisata medis.

2) Kehidupan sosial budaya masyarakat, dalam menerapkan pengetahuan. Di zaman modern seperti sekarang sangat menarik untuk berbicara tentang kehidupan masyarakat desa karena pola hidup mereka sangat berbeda dari masyarakat saat ini. Ketika kita berbicara tentang komunitas desa tidak akan terlepas dari gaya hidup tradisional baik dari segi interaksi sosial kehidupan dengan orang lain maupun dengan lingkungan sekitarnya yang masih didominasi oleh kebiasaan lama. Bea cukai adalah aturan yang mapan dan mencakup semua konsepsi sistem budaya yang mengatur tindakan atau perbuatan manusia dalam kehidupan mereka. Dengan demikian, masyarakat Desa Wanagiri, Bedugul tradisional dalam menjalankan hidup mereka berdasarkan cara atau kebiasaan lama masih diwarisi dari leluhur mereka. Kehidupan mereka belum begitu dipengaruhi oleh perubahan yang datang dari luar lingkungan sosial mereka. Budaya masyarakat tradisional adalah hasil adaptasi terhadap lingkungan alam dan sosial sekitarnya tanpa menerima pengaruh dari luar. Salah satu contoh yang digunakan untuk tanaman medis yang berfungsi sebagai alternatif dalam pengobatan yang bersifat tradisional yang didasarkan pada 
filsafat budaya dan agama Hindu, sumber ajaran yang terkandung dalam lontar husada.

3) Lingkungan yang belum rusak. Kondisi lingkungan Desa Wanagiri, Bedugul masih terlihat masih indah dimana Desa Wanagiri, Bedugul belum tersentuh oleh berbagai perkembangan, dimana sebagian besar lahan digunakan untuk sawah. Tanah-tanah rumah dimanfaatkan sebagai pengembangan tanaman medis sehingga vegetasi berbagai jenis tanaman obat yang dikonservasi oleh masyarakat, serta yang tumbuh liar masih dilestarikan di habitatnya, sehingga kebutuhan akan kuantitas tanaman Medis masih terpenuhi. Kondisi fisik jalan di dalam desa sangat mendukung. Jalan ini sangat berpengaruh dalam mengembangkan daya tarik wisata yang potensial. Jika akses jalan untuk berwisata ke tempat wisata tidak mencukupi, pasti orang akan malas mengunjunginya. Akses jalan adalah salah satu kemudahan dalam kegiatan pariwisata dengan kondisi jalan yang baik, wisatawan akan merasa mudah untuk mencapai lokasi yang dimaksud.

4) Kondisi iklim dan keamanan yang mendukung. Kondisi iklim Desa Wanagiri, Bedugul stabil sehingga vegetasi tanaman Medis tetap terjaga, selain itu wisatawan dapat mengunjungi Desa Wanagiri, Bedugul tanpa hambatan apapun terhadap perubahan iklim. Selain iklim, faktor keamanan sangat mendukung tujuan untuk terus tumbuh. Stabilitas keamanan Desa Wanagiri, Bedugul sangat kondusif karena keterlibatan warga desa dalam memobilisasi persatuan dan kesatuan dalam semangat kerjasama antar warga desa masih sangat kuat.

b. Kelemahan

Desa Wanagiri juga memiliki beberapa kelemahan, berikut adalah paparan kelemahan Desa Wanagiri: 
1) Kualitas Sumber Daya Manusia Lokal.

Sumber daya manusia lokal masih rendah. Hal ini dapat dilihat dari tingkat pendidikan dan penghidupan mereka sebagian besar penduduk Desa Wanagiri, mata pencaharian Bedugul sebagai petani sehingga ini akan berdampak pada:

Sebuah kemampuan untuk mengelola dan mengembangkan, potensi wisata masih minim dan tidak merata, dikarenakan; (1) keterampilan bahasa asing yang rendah, (2) kurangnya pengetahuan di bidang pariwisata, (3) kurangnya ahli. Dari beberapa hal di atas akan langsung mempengaruhi produk wisata yang ditawarkan kepada wisatawan.

2) Informasi Terbatas.

Ini biasanya sering dialami oleh masyarakat pedesaan, terutama masyarakat Desa Wanagiri, Bedugul. Keterbatasan informasi baik melalui media elektronik atau media massa tentang semua bentuk perubahan dan perkembangan global, yang dapat menyebabkan kesenjangan dalam berbagai aspek seperti pemahaman yang rendah, kurangnya kreativitas dan langkah-langkah inovatif dalam pengembangan produk pariwisata medis yang potensial. Juga disadari bahwa tidak semua masyarakat pedesaan dapat menggunakan teknologi informasi yang telah dikembangkan saat ini, salah satu contohnya adalah melalui internet.

3) Fasilitas Pendukung Masih Kurang.

Intinya, fungsi fasilitas harus untuk melayani dan memfasilitasi kegiatan atau kegiatan pengunjung / wisatawan yang dilakukan agar mendapat pengalaman rekreasi. Selain itu, fasilitas juga bisa menjadi daya tarik wisata. Fasilitas yang disajikan dengan wisatawan perhotelan yang menyenangkan bisa menjadi trik, di mana keramahan dapat mengangkat penyediaan layanan menjadi daya tarik wisata sehingga wisatawan benar-benar merasa puas tidak hanya dalam hal 
perawatan medis tetapi juga dalam hal fasilitas pelayanan pariwisata. Namun ketersediaan fasilitas di Desa Wanagiri, Bedugul masih sangat terbatas dimana fasilitas seperti penginapan dan restoran masih sangat minim. Kelemahan fasilitas pariwisata menjadi kendala yang menjadi faktor pendukung pengembangan pariwisata medis.

c. Kesempatan

Berdasarkan kekuatan dan kelemahan Desa Wanagiri, berikut kesempatan/potensi yang bisa dikembangkan oleh masyaarkat sekitar:

1) Produk pariwisata digolongkan baru.

Produk pariwisata medis merupakan salah satu produk wisata alternatif yang baru, walaupun di luar negeri juga memiliki jenis wisata yang sama tetapi jenis kemasan dan nilai filosofi sangat berbeda dan memiliki cirri tersendiri yang memiliki daya tarik tersendiri bagi wisatawan, dan tingkat persaingan di dalam industri pariwisata tidak terlalu ketat.

2) Tren Meningkatnya Pariwisata Medis

Hal ini dapat dilihat telah muncul wisata medis di banyak negara sebagai bentuk perdagangan yang memiliki nilai tambah bagi produk pariwisata. Negara-negara ini telah secara aktif berkembang menjadi industri yang menerima dukungan dan investasi pemerintah. Diperkirakan bahwa industri pariwisata medis global saat ini menghasilkan pendapatan tahunan hingga US \$ 60 miliar (negatif 40 miliar), terhadap pertumbuhan tahunan sebesar 20\% (Horowitz, Rosensweig, \& Jones, 2007). Saat berada di Indonesia. Karena, selama ini model perawatan alternatif belum banyak digali, sementara banyak wisatawan asing datang ke Indonesia tertarik dengan obat alternatif semacam itu.

"Ini kenyataan. Banyak turis asing datang untuk menikmati perawatan kesehatan alternatif dan bisa menjadi bisnis wisata komersial," 
3) Segmen Pasar Nasional dan Internasional

Daya tarik wisata medis kepada konsumen (wisatawan) baik secara nasional maupun internasional terus berkembang. Hal ini dapat dilihat dari meningkatnya jumlah wisatawan medis, dari 19 juta wisatawan pada tahun 2005. menjadi 25,8 juta pada tahun 2007, dengan tingkat pertumbuhan tahunan sebesar 16,5\% (RNCOS, 2008). Mengingat ini membuktikan bahwa saat ini banyak orang yang cukup tertarik dengan munculnya wisata medis. Ini merupakan peluang bagi Desa Wanagiri, Bedugul untuk bergerak di bidang pariwisata dalam mengembangkan pariwisata medis.

Memahami pengertian pasar pariwisata dapat dijelaskan melalui pemahaman permintaan pariwisata oleh (Mathieson dan Wall), adalah jumlah total orang yang bepergian atau ingin bepergian untuk menggunakan fasilitas dan layanan wisata di tempat yang jauh dari tempat mereka tinggal dan bekerja.

4) Budaya Bali

Hal ini didukung oleh pelestarian budaya Bali sebagai budaya lokal yang terus dilestarikan yang menjadi diri masyarakat Bali terutama Desa Wanagiri, Bedugul sehingga unsur-unsur nilai filosofis yang melekat dalam wisata medis tidak hilang dan terpelihara.

a) Sebagai salah satu langkah konservasi

Dengan adanya wisata medis dengan kata lain lingkungan alam yang ada di sekitar Desa Wanagiri, Bedugul banyak tumbuhtumbuhan yang ditutupi dengan berbagai tanaman Medis akan dijaga.

b) Membuka bidang pekerjaan.

Dengan adanya wisata medis sebagai alternatif wisata di Desa Wanagiri, Bedugul secara otomatis akan diserap juga sejumlah tenaga kerja yang ada, baik dari pengembangan pariwisata 
medisnya sendiri maupun dari fasilitas pendukung lainnya seperti akomodasi restoran dan fasilitas transportasi.

\section{d. Ancaman}

Selain kesempatan yang sudah dijelaskan di atas, ada juga ancaman-ancaman yang mungkin akan muncul.

1) Pembangunan yang tidak terkendali di Bali pada umumnya

Penetrasi industri pariwisata di Bali membawa dampak dan perubahan yang sangat pesat, terutama dalam hal pengembangan fasilitas infrastruktur pariwisata yang berdampak pada penggunaan lahan, hal ini dianggap mengancam keberlangsungan wisata medis di Desa Wanagiri, Bedugul karena dengan tidak terkontrol dapat mempengaruhi perubahan fungsi lahan pedesaan dari alam akan tersentuh oleh berbagai perkembangan yang pada akhirnya merusak nilai estetika tanah sebelumnya.

2) Adanya persaingan di antara pengembang produk sejenis

Hal ini dianggap sebagai ancaman karena kita menyadari bahwa khususnya di daerah Bali berbagai jenis tanaman medis juga banyak tersebar di beberapa tempat lain, terutama di desa-desa lain selain di Desa Wanagiri, Bedugul, dengan filosofi yang sama akan timbul persamaan atau kesamaan yang akan menyebabkan persaingan yang ketat di dalam wilayah Bali itu sendiri.

\section{DESAIN PRODUK WISATA MEDIS DI DESA WANAGIRI}

Produk yang kami desain di Desa Wanagiri, Bedugul dibagi menjadi dua jenis:

\section{a. Belajar dan Berlatih Herbal}

Paket wisata ini adalah paket wisata yang ditawarkan bagi mereka yang ingin mengetahui jenis tanaman medis dan proses pengolahannya. Kegiatan yang terkandung dalam paket ini dimulai dari pengenalan 
tanaman medis untuk berlatih mengolahnya. Wisatawan tidak hanya mendapatkan pengetahuan tentang tanaman medis tetapi juga dapat menjaga kesehatan atau menyembuhkan diri dari stres dan rutinitas.

Sebuah. pengantar

Pada sesi ini wisatawan akan diberikan informasi awal tentang tanaman Medis (filosofi dan kegunaannya). Sesi pengenalan akan dipandu oleh kepala Desa Wanagiri, Bedugul yang didampingi oleh pemandu wisata.

1) Melacak di Sekitar Desa

Wisatawan akan diajak berkeliling desa untuk melihat langsung tanaman Medis ke ladang penduduk dan jalan desa. Waktu perjalanan sekitar 3-4 jam termasuk istirahat dan mengambil foto pemandangan sekitarnya.

2) Pembuatan Jamu (Minuman Herbal)

Dalam kegiatan ini, wisatawan akan diajak melihat proses pengolahan dan pengolahan langsung tanaman Medis menjadi herbal, boreh dan body mask dengan bahan yang telah disiapkan sebelumnya. Pemrosesan dilakukan berdasarkan resep yang telah dirancang oleh masyarakat setempat (tabel 3). Setelah sesi berakhir, wisatawan akan dilayani jamu / minuman herbal dan diberikan hadiah dari jamu.

3) Perawatan Selama Tinggal

Dalam produk kunci ini, pasien dengan tingkat penyakit kritis akan dipelihara di area khusus seperti sebuah penginapan, dengan kepastian untuk mendapatkan penyembuhan. Dalam bisnis perawatan, banyak tanaman medis di sekitar Desa Wanagiri, Bedugul akan ditambahkan dengan pengobatan alternatif Usada. Perawatan dan penginapan akan dipandu oleh dokter khusus, seorang ahli spiritual Bali, dan perawat siaga 24 jam. Jenis perawatan dan fasilitas yang diperoleh disesuaikan dengan harga yang dibayarkan. 
b. Perawatan Kesehatan

Paket wisata ini adalah perawatan kesehatan dan penyembuhan penyakit dengan ramuan Medis tradisional. Wisatawan yang ingin melakukan aktivitas perawatan medis, akan dirawat dengan menggunakan ramuan obat tradisional sesuai dengan keluhan. Wisatawan akan dirawat di rumah-rumah penduduk, mengikuti aktivitas penduduk setempat dan dirawat dengan makanan dan minuman tradisional yang disesuaikan dengan keluhan kesehatan para wisatawan. Lama pengobatan 5-10 hari tergantung keluhan yang diderita pasien, biasanya untuk kasus penyakit ringan.

\section{PRODUK PARIWISATA MEDIS}

Harga produk yang ditawarkan akan sangat bervariasi tergantung pada jenis penyakit, usia, dan fasilitas yang akan dinikmati. Deskripsi harga produk akan dimasukkan dalam tabel di bawah ini.

Deskripsi Harga

\begin{tabular}{|l|l|l|l|}
\hline Price Types & $50 \$$ night & $100 \$ /$ night & $200 \$ /$ night \\
\hline Time & $1-3$ night & $1-3$ week & $1-2$ month \\
\hline $\begin{array}{l}\text { Type of } \\
\text { Disease }\end{array}$ & $\begin{array}{l}\text { Low type of } \\
\text { disease } \\
\text { (rheumatism, } \\
\text { gout, stress, } \\
\text { insomnia) }\end{array}$ & $\begin{array}{l}\text { Medium type of } \\
\text { disease } \\
\text { (addictive substance } \\
\text { addiction, mild stroke, } \\
\text { sexual dysfunction } \\
\text { disorder) }\end{array}$ & $\begin{array}{l}\text { High type of } \\
\text { disease } \\
\text { (diabetes, heart } \\
\text { disease, } \\
\text { amnesia, } \\
\text { cancer) }\end{array}$ \\
\hline Ages & 20-40 years old & 40-60 years old & 60 years old \\
\hline Facilities & $\begin{array}{l}\text { Bedroom, Air } \\
\text { conditioner, sport } \\
\text { facilities }\end{array}$ & $\begin{array}{l}\text { Bedroom, } \\
\text { Airconditioner, } \\
\text { medical therapy (1 } \\
\text { time per day) }\end{array}$ & $\begin{array}{l}\text { Bedroom with } \\
\text { living room, air } \\
\text { conditioner, } \\
\text { private butler, } \\
\text { and medical } \\
\text { therapy (3 } \\
\text { times in a day) }\end{array}$ \\
\hline
\end{tabular}

Kelebihan produk ini antara lain:

a. Menawarkan konsep pariwisata unik yang menggabungkan kesehatan dan pariwisata, yaitu layanan medis alternatif. 
b. Wisatawan dapat memperoleh pengetahuan baru, terutama tentang tanaman medis dan pengolahannya dan merupakan pengetahuan asli Indonesia.

c. Produk ini dapat dilaksanakan kapan saja, tidak dipengaruhi oleh musim dan didukung oleh kondisi geografis dan sosial desa dari masyarakat.

d. Pengembangan produk ini selain memberikan manfaat kepada wisatawan juga dapat memberikan manfaat bagi masyarakat desa dalam bentuk lapangan kerja dan konservasi alam.

Termasuk produk pariwisata baru, di mana belum banyak pesaing

\section{SEGMEN PASAR}

Untuk waktu yang lama, pasien mungkin mendapati diri mereka terpaksa membayar harga yang tidak mampu mereka bayar - kadangkadang untuk operasi yang merupakan kebutuhan. Anda tidak harus membuat pilihan antara membayar sewa dan menjalani biaya medis yang mahal; Berkat pariwisata medis, ini sekarang menjadi kenyataan bagi banyak orang. Terbang ke luar negeri untuk kebutuhan medis Anda dapat sangat mengurangi pengeluaran Anda. Ribuan orang bergabung dengan revolusi pariwisata medis setiap tahun, terkadang menghemat banyak uang dalam prosesnya. Bahkan, laporan terbaru oleh firma konsultan manajemen memimpin, Deloitte, menyatakan bahwa pada tahun 2007 2m pengawas wisata Amerika untuk perawatan, dan tingkat itu kami akan tumbuh menjadi 6 juta pada tahun 2010 dan setinggi 20 juta pada tahun 2015.

Alasan lain untuk menuju ke luar negeri mungkin termasuk kemajuan teknologi atau perputaran yang lebih cepat dari konsultasi hingga prosedur daripada yang tersedia di negara asal pasien. Wisata medis dengan cepat menjadi cara yang diterima untuk memenuhi persyaratan 
medis - baik untuk kosmetik, gigi, operasi atau alasan lainnya - sekarang ini adalah fenomena global yang terus berkembang. Analisis terkini dari pasar pariwisata medis menunjukkan:

a. $45 \%$ orang Amerika Utara melakukan perjalanan ke Asia untuk perawatan medis di luar negeri, dengan 26\% bepergian ke Amerika Selatan.

b. $33 \%$ orang Eropa melakukan perjalanan ke Amerika Utara, 39\% ke Asia dan $10 \%$ ke negara lain di benua itu

c. $87 \%$ pasien wisata medis melakukan perjalanan dari Selatan ke Amerika Utara, bersama dengan 33\% pasien Eropa dan 58\% dari Timur Tengah

Berdasarkan statistik tersebut, program kami untuk pariwisata medis akan berfokus pada Amerika Utara dan Eropa yang ingin melakukan perjalanan ke Asia, untuk melakukan perawatan medis. Mereka memiliki profil unik seperti: biasanya sudah pensiun, bepergian dengan keluarga atau anak-anak, ingin tinggal cukup jauh dari pusat kota, dan tidak ingin menghabiskan banyak biaya transportasi.

Pasar yang kami layani adalah wisatawan asing dari semua lapisan masyarakat serta usia yang ingin melakukan perawatan kesehatan dan wisatawan yang ingin belajar teknik perawatan kesehatan tradisional Bali melalui tanaman medis dan produk susu mereka. Kami memilih pangsa pasar turis asing, terutama turis Eropa dan Amerika, karena di kalangan turis asing, terutama turis Eropa dan Amerika, terapi medis tradisional menggunakan tanaman medis sangat langka dan tentunya ini adalah daya tarik utama bagi segmen pasar ini. Selain itu, ada yang dilihat dari sisi pasar permintaan, pariwisata Back to Nature sangat populer oleh turis Amerika dan Eropa. Dengan kata lain, para wisatawan yang kami layani adalah wisatawan yang memiliki minat di bidang kesehatan, terutama kesehatan 
tradisional. Pasar ini merupakan ceruk pasar (niche market), di mana masih belum banyak produk pariwisata yang melirik segmen pasar ini di Bali.

Tabel Segmen Pasar

\begin{tabular}{|l|l|l|}
\hline & \multicolumn{1}{|c|}{ Demografi } & \multicolumn{1}{c|}{ Area } \\
\hline Main market segment & Retired, age above than 60 years old & Western \\
Second market segment & At the end of productive age & Europe \& \\
\cline { 1 - 2 } Third market segment & Productive Age & American \\
\hline
\end{tabular}

\section{KESIMPULAN DAN SARAN}

Desa Wanagiri, Bedugul memiliki kelebihan dalam kondisi alaminya yang menarik dan kedekatan posisinya dengan Kebun Raya Eka Karya sehingga memiliki potensi besar untuk industri perjalanan. Tur yang akan dijalankan di desa ini akan lebih spesifik karena akan bergantung pada kekayaan tanaman obat yang tumbuh di sekitar pedesaan ini. Hal lain adalah pengembangan berbagai jenis wisata alternatif dengan jenis wisata selama ini yang dikembangkan di daerah Bedugul.

Peluang untuk pengembangan budidaya tanaman obat masih sangat terbuka lebar seiring dengan pertumbuhan jamu industri, obatobatan, herbal, fitofarmaka dan kosmetik tradisional. Dalam kaitannya dengan pariwisata, penggunaan tanaman medis tentu bisa menjadi daya tarik bagi wisatawan untuk mengetahui jenis, pemanfaatan dan pengolahan tanaman medis untuk siap konsumsi. Selain itu, khasiat tanaman medis untuk menyembuhkan penyakit dan mengobati kesehatan bisa menjadi layanan medis bagi wisatawan.

Setiap turis akan dikenakan biaya berbeda tergantung pada tingkat penyakit dan usia pasien. Selain itu, kegiatan pariwisata yang dipilih akan menentukan diversifikasi harga berikutnya. Diharapkan melalui kegiatan wisata alternatif ini, manfaatnya tidak hanya dirasakan oleh wisatawan yang datang (tentu saja dalam bentuk penyembuhan penyakit), tetapi juga untuk masyarakat sekitar di Desa Wanagiri, Bedugul. 


\section{DAFTAR PUSTAKA}

Adiputra, N (2006) Horticulture which is considered as Medical plants in some governmental offices in Badung and Denpasar City. Udayana Medical Journal, 37 (131): 29-38.

Atmodjo, Wasti. 2011. Thriving spas draw tourists to Bali. The Jakarta Post. February 12, 2011. http://www.thejakartapost.com/news/2011/02/12/thriving-spasdraw-tourists-bali.html.

Bali to Become a Health Tourism Destination. The Beat. March 10, 2011. http://beatmag.com/latest-news/bali-to-become-a-health-tourismdestination.html.

B. Utomo. 2011. Pengobatan Herba Kelas Professional. Malang: School of Traditional Medicine PULE-3

B. Utomo. 2007. Dasar-Dasar Penyembuhan Tradisional. Malang: School of Traditional Medicine PULE-3

Chitakasem, Parita. 2011. Spa tourism is big business in Asia Pacific. Euromonitor Global Market Research Blog. January 11, 2011. http://blog.euromonitor.com/2011/01/spa-tourism-is bigbusinessin-asia-pacific.html.

Ehrbeck, T.; Guevara, C.; and Mango, P.D. 2008. Mapping the Market for Medical Travel. The McKinsey Quarterly. May 2008. http://www.mckinseyquarterly.com/Mapping_the_market_for_tra vel_2134.

Herrick, Devon M. 2007. Medical Tourism: Global Competition in Healthcare. National Center for Policy Analysis. November 2007. http://www.unf.edu/brooks/center/pdfs/Medical\%20Tourism\%20 Herrick.pdf.

Keckley, Paul and Underwood, Howard. 2008. Medical Tourism: Consumers in Search of Value. Deloitte. http://www.deloitte.com/assets/DcomCroatia/Local\%20Assets/D ocuments/hr_Medical_tourism(3).pdf.

Kelley, Edward. 2013. Medical Tourism WHO Patient Safety Programme. World Health Organization: A World Alliance for Safer Health Care.

Lunt, Neil., Smith, Richard., Exworthy, Mark., Green, Stephen T. Medical Tourism: Treatments, Markets and Health System Implications: A scoping review. OECD. Directorate for Employment, Labour and Social Affairs.

McKinsey \& Company., 2008. Effectively Characterizing Medical Travel: Current and Potential State. Available from: http://McKinseyQuarterly.com. 
Raymond, Obomsawin .2008. The efficacy \& safety of Traditional plant medicines. National aboriginal health organization Ottawa, Ontario Canada.

Stephano, Renee-Marie and Erazo, Christin. 2009. Health Tourism - The Integration of Health and Medical Wellness. Health Tourism Magazine July 15 , 2009. http://www.healthtourismmagazine.com/articledetail.php?issue $=$ issue-1\&article=Integration.

Woodman, F., 2007. Patients Beyond Borders. Deloitte Development LLC. "Medical Tourism: Consumers in Search of Travel.

Youngman, Ian. 2009. Medical tourism statistics: Why McKinsey has got it wrong. International Medical Travel Journal. 2009. http://www.imtj.com/articles/2009/mckinsey-wrong-medicaltravel.

SK Menkes No. 149/SK/Menkes/IV/1978

www. PULE-3.com

www. wikipedia.com /tanaman obat 